\title{
The right to defense in proceedings on cases of administrative offenses
}

\author{
Yulia Anikeenko*, Maria Gracheva, and Natalia Novoselova \\ Ural State Law University, Department of Administrative Law, 620000 Komsomolskaya 21, Yekaterinburg, Russia
}

\begin{abstract}
The authors reflect on the further prospects for their development based on the results of the analysis of the current Code of Administrative Offenses of the Russian Federation, the draft Code of the Russian Federation on Administrative Offenses and the Procedural Code of the Russian Federation on Administrative Offenses. They also include foreign legislation, modern points of view on the development of administrative tort legislation. The attention is focused on the conceptual issues of the right of citizens to defense in proceedings on cases of administrative offenses.
\end{abstract}

\section{Introduction}

The right to defense in proceedings on cases of administrative offenses is a basic principle of administrative tort law. In Part 1 of Art. 25.1, 25.5 of the Code of Administrative Offenses of the Russian Federation, the principle of the right to defense is implemented by granting the subject brought to administrative responsibility the right to familiarize oneself with all the materials of the case, give explanations, present evidence, file petitions, appeal against decisions. When considering a case, one can use the assistance of a defense attorney, etc. The principle of presumption of innocence enshrined in Article 1.5 of the Administrative Code of the Russian Federation should also be considered as an element of the right to defense [1] (parts 1 and 4 of Article 1.5 of the Code of Administrative Offenses of RF). According to it, a party is subject to administrative responsibility only for those administrative offenses in respect of which its guilt is established. Moreover, irremediable doubts about the guilt of a subject brought to administrative responsibility are interpreted in its favor.

\section{Materials and methods}

In the draft Procedural Code of the Russian Federation on Administrative Offenses (hereinafter - the draft ProCoAO RF), the principle of the presumption of innocence has undergone significant changes [2]. Thus, in Part 1 of Article 1.5 of the draft ProCoAO RF, it is established that a subject against whom proceedings are being conducted on an administrative offense is considered innocent of committing an administrative offense. It takes place until its guilt (the illegality of an action (inaction) is proved in accordance with the procedure provided for by this Code, and is established by the decision of the subject of administrative jurisdiction that has entered into legal force. It is obvious that an attempt is being made to establish guilt to supplement or replace the clarification of the unlawfulness of the act, i.e. investigate only objective signs of an administrative offense. At the same time, it is not indicated which subject is in question: an individual or a legal entity. If for a legal entity the category of guilt in its classical scientific understanding as the mental attitude of a person to the act, being committed is inapplicable due to the absence of psyche. Then for an individual with such an unclear and ambiguous concept of the presumption of innocence, Part 1 of Art. 1.5 of the draft ProCoAO RF may lead to objective imputation.

Part 2 of Article 1.5 of the draft ProCoAO RF contains another "novelty": the guilt of a legal entity in committing an administrative offense is assumed if there is evidence that it was committed by officials, employees and (or) representatives of the legal entity of illegal actions (inaction) or of a harmful consequences of these actions (inaction). A similar interpretation of the guilt of legal entities is already used in Part 4 of Article 110 of the Tax Code of the Russian Federation: The guilt of an organization in committing a tax offense is determined depending on the guilt of its officials or its representatives, whose actions (inaction) caused the commission of this tax offense.

Moreover, in the second paragraph of Part 2 of Art. 1.5. the draft ProCoAO RF refutes the need to establish the guilt of a legal entity through a study of the guilt of its employees as a basis for releasing a subject from administrative responsibility. Failure to establish the guilt of an official, employee and (or) a representative of a legal entity in committing an administrative offense cannot serve as a basis for releasing a legal entity from administrative responsibility for committing this administrative offense.

Also, the right to defense can be attributed to the provisions of Art. 25.1, 25.4 of the Code of

\footnotetext{
Corresponding author: $\underline{\text { avanik@e1.ru }}$
} 
Administrative Offenses of the Russian Federation. According to it, in the absence of a person in respect of whom proceedings are underway in an administrative offense case, a legal representative of a legal entity brought to administrative responsibility, or its defender, the case can be considered. It can happen only if there is evidence of a proper notice of the place and time of the consideration of the case and if a petition to postpone the consideration of the case has not been received or if such a petition was dismissed [3]. The Administrative Code of the Russian Federation names only three categories of cases. In them, the presence of an individual brought to administrative responsibility is mandatory, and the case cannot be considered in his absence. If an administrative offense committed by him entails administrative arrest, administrative expulsion from the Russian Federation of a foreign citizen or a stateless person, or mandatory work.

As a measure aimed at protecting the rights of a minor who is brought to administrative responsibility, one can consider the possibility of removing him from the premises where the case of an administrative offense is being considered. At the same time, while considering the circumstances of the case, the their discussion may have a negative impact on the minor (Part 4 of Art. 25.1 of the Administrative Code of the Russian Federation). Another measure to protect the rights of minors brought to administrative responsibility is the requirements enshrined in Art. 29.4, 29.7 of the Code of Administrative Offenses of the Russian Federation, according to which the presence of a legal representative of an individual brought to administrative responsibility is mandatory if the individual against whom the case of an administrative offense is being conducted is a minor. If the persons whose participation is recognized as mandatory fail to appear without a valid reason, and their absence prevents a comprehensive, complete, objective and timely clarification of the circumstances of the case and its resolution in accordance with the law, the judge, body, official considering the case shall issue a ruling on the forced delivery.

\section{Results}

The right to defense in proceedings on cases of administrative offenses is also exercised through the provision of legal assistance. Administrative and legal science highly appreciates the importance of the norms of the Code of Administrative Offenses of the Russian Federation aimed at obtaining qualified legal assistance in proceedings on cases of administrative offenses [4, 18]. Legal assistance to a person in respect of whom a case of an administrative offense is being conducted is provided by a defender, the victim - by a representative (part 1, article 25.5 of the Administrative Code of the Russian Federation). An advocate or other person shall be allowed to participate in proceedings on a case on an administrative offense as a defender or representative. The Commissioner under the President of the Russian Federation for the protection of the rights of entrepreneurs may be admitted as a defender, according to Art. 1 of the Code of Administrative Offenses of the Russian Federation, at the request of the person in respect of whom the proceedings are underway in the case of an administrative offense in the area of entrepreneurial activity.

An advocate is a person who, in accordance with the procedure established by Federal Law No. 63-FZ of 31.05.2002 "On advocacy and the legal profession in the Russian Federation", has received the status of an advocate and the right to practice advocacy. The powers of an advocate are certified by a warrant issued by the relevant advocate organization. Providing legal assistance, an advocate participates as a representative or defender of the client in proceedings on cases of administrative offenses. Interference in the advocacy activity carried out in accordance with the law, or hindering this activity in any way, is prohibited. An advocate may not be called and questioned as a witness about the circumstances that have become known to him in connection with applying to him for legal assistance or in connection with its provision. It is not allowed to request information related to the provision of legal assistance in specific cases from advocates, as well as from employees of advocacy organizations, chambers of advocates or the Federal Chamber of Advocates. Advocate activity is carried out on the basis of an agreement between the advocate and the client. The agreement is a civil contract concluded in a simple written form between the client and the advocate for the provision of legal assistance to the client himself or to a person appointed by him.

The advocate acts as a representative of the principal in legal proceedings in cases of administrative offenses and represents the interests of the principal in public authorities, local governments only on the basis of an assignment agreement. No qualification requirements are imposed on any other person who is positioned by the Code of Administrative Offenses of the Russian Federation as a defender or representative. As a rule, employees of law departments of legal entities that are brought to administrative responsibility or are victims act in this capacity. The powers of another person providing legal assistance are certified by a power of attorney drawn up in accordance with the law. A person cannot be a defender and a representative if he is an employee of state bodies exercising supervision and control over the observance of the rules. The violation of the rules was the basis for initiating this case, or if he previously acted as another participant in the proceedings in the case of an administrative offense (Part 1 of Art. 25.12 of the Code of Administrative Offenses of the Russian Federation).

Y. Serebryakov believes that the participation of a defense attorney in proceedings in cases of administrative offenses is an important guarantee of the rights and freedoms of subjects in respect of which proceedings are carried out in cases of administrative offenses [5].

Persons may not be defenders and representatives if they are employees of state bodies that exercise supervision and control over compliance with the rules. The violation of the rules was the basis for initiating this 
case, or if they previously acted as other participants in the proceedings on an administrative offense (part 1 of Article 25.12 of the Administrative Code of the Russian Federation).

In the draft ProCoAO RF, the right to legal assistance in proceedings on cases of administrative offenses has also undergone significant changes. So, in parts 1, 4 of article 1.11 of the draft ProCoAO RF, the subject in respect of which the proceedings are underway in the case of an administrative offense, the victim, as well as in cases provided for by law, other participants in the proceedings on cases of administrative offenses are guaranteed state protection of their rights and legitimate interests in proceedings on cases of administrative offenses. In the cases provided for by this Code, legal assistance is provided free of charge.

These provisions of the draft ProCoAO RF, at first glance, correspond to Part 1 of Art. 48 of the Constitution of the Russian Federation, according to which everyone is guaranteed the right to receive qualified legal assistance. In cases stipulated by law, legal assistance is provided free of charge, however, such cases have not been established in the ProCoAO RF draft. Currently, a proposal is being discussed to guarantee a citizen who may be imposed an administrative penalty in the form of administrative arrest, the right to provide professional legal assistance free of charge [6]. At the same time, it is also necessary to support the opinion of O. Chumakova, who believes that free legal assistance in cases of administrative offenses should be provided only to individuals [7].

The Federal Law of November 21, 2011 No. 324-FZ "On Free Legal Aid in the Russian Federation" does not establish a mechanism for obtaining free legal aid. The Federal Law "On the Advocacy in the Russian Federation" of May 31, 2002 No. 63-FZ also does not provide for "... a mechanism for the implementation of this obligation, responsibility for refusing to provide assistance" [8]. R. Vitske considers it unfair for an advocate to enter the criminal and civil process at the expense of the state, despite the fact that in proceedings on cases of administrative offenses, the participants are deprived of such an opportunity [9]. The only case when, according to the current legislation, free legal assistance is provided in the proceedings on administrative offenses is fixed in Article 8 of the Federal Law of June 24, 1999 No. 120-FZ. Its title is "On the basics of the system of prevention of neglect and juvenile delinquency" in relation to minors who must be provided with free legal assistance with the participation of lawyers, as well as other persons entitled to legal assistance in accordance with the law. According to A. Shadzhe and others in the aggregate of the existing legal norms, it can be stated that the provision of free legal assistance established by law is ensured by the appointment of an advocate by an authorized body or official and is an unconditional obligation of the advocacy [10]. Some authors believe that the provision of all types of free legal aid should be dealt with exclusively by advocates [11], which, of course, is not an indisputable position.

The victim is also entitled to protection and can protect his interests by applying for petitions, filing a complaint, getting acquainted with the case materials. Despite the wide scope of procedural rights presented to the victim by the Administrative Code of the Russian Federation, it should be noted that the recognition of a party as a victim is entirely its initiative. A party can initiate itself as a victim at the stage of filing an application containing data indicating the existence of an event of an administrative offense, at the stage of drawing up a protocol on an administrative offense, at the stage of considering an administrative offense case until the decision on the case is made by filing a petition. The Administrative Code of the Russian Federation does not contain an independent procedural document on recognition as a victim in proceedings on administrative offenses. Since most of the constructions of the Administrative Code of the Russian Federation are formal, there is no need for the judge, body, official in whose proceedings the case of an administrative offense is possessed to establish socially harmful consequences as a mandatory sign of the construction of an administrative offense. In most cases, a party cannot initiate itself as a victim, since it does not even know about the initiated case.

In the draft ProCoAO RF it is planned to seriously change the very institution of representation in proceedings on cases of administrative offenses. The terminology itself will change the representative of the subject in respect of which the proceedings are underway in the case of an administrative offense (according to the current Code of Administrative Offenses of the Russian Federation - the defender) and the representative of the victim.

A representative acting on the basis of a power of attorney has the right to perform on behalf of the person he represents, all procedural actions in proceedings in an administrative offense case specified in the power of attorney issued to him for representing interests in proceedings in an administrative offense case. At the same time, the draft ProCoAO RF imposes increased requirements for issuing a power of attorney to participate in proceedings on cases of administrative offenses as a representative. In part 9-11 of article 2.3 of the draft ProCoAO RF, Art. 53 of the Code of Civil Procedure of the Russian Federation (registration and confirmation of the powers of a representative), it was established that powers of attorney issued by citizens for representation in proceedings on an administrative offense are certified by a notary or by an official of the organization. In them the principal studies, works are performed by a partnership of homeowners, a housing, housing construction or other specialized consumer cooperative.

That manages an apartment building, a management organization at the principal's place of residence, the administration of the social security institution in which the principal is located, and a stationary medical institution in which the principal is monitored or treated. Powers of attorney issued by military personnel, employees of military units, formations, institutions, military educational institutions or members of their families are certified by the commander of the corresponding unit, institution, military educational 
institution. The powers of attorney of persons who are in places of detention or in places of deprivation of freedom are certified by the head of the relevant institution. A power of attorney on behalf of an individual entrepreneur for representation in the proceedings on an administrative offense case must be signed by him and sealed with his seal, if available, or may be certified in accordance with part 9 of this article. A power of attorney on behalf of a legal entity for representation in the proceedings on an administrative offense must be signed by its head or another person authorized to do so by its constituent documents and sealed with the seal of the legal entity, if it exists.

The current Code of Administrative Offenses of the Russian Federation does not contain issues of registration and confirmation of the powers of a defender (representative). In part 15 of Article 2.3 of the draft ProCoAO RF, it is established that if the subject in respect of which the proceedings are underway in the case of an administrative offense, or the victim submits a petition to involve a representative, including an advocate, to participate in the case of an administrative offense, then such a representative, including an advocate, must be allowed to participate in a case of an administrative offense. This can happen without presenting an appropriate power of attorney from an authorized person or an order from an advocate. Currently, there is no such norm in the Code of Administrative Offenses of the Russian Federation, but a similar law enforcement practice exists when bringing to administrative responsibility in court.

The legislation of the post-Soviet countries on administrative offenses also formulates the concept of a representative in the proceedings on administrative offenses in different ways and establishes his legal status. Thus, the Procedural and Executive Code of the Republic of Belarus on Administrative Offenses [12] names a defender and a representative among the participants in the proceedings on administrative offenses (Article 4.5).

Advocates who are citizens of the Republic of Belarus may participate in the administrative process as a defender of an individual against whom an administrative process is being conducted; advocates who are foreign citizens and stateless persons - in accordance with international treaties of the Republic of Belarus. At the request of an individual against whom an administrative process is being conducted, a legal representative or one of the close relatives of the person against whom the administrative process is being conducted may be admitted as a defender by the decision of the body conducting the administrative process. As a representative of the victim, who is an individual entrepreneur, in respect of whom an administrative process is being conducted, advocates, legal representatives, close relatives, other persons performing representation in cases provided for by legislative acts may participate in the administrative process.

The Code of Administrative Offences of the Republic of Azerbaijan [13], in articles 65 and 66, respectively, contains the concepts of "defender" and "representative", "advocate". Moreover, only an advocate is allowed to participate in the proceedings under consideration by the court in the case of an administrative offense as a defender of an individual, and his close relative or advocate is allowed as a representative of the individual victim.

In the Code of Administrative Offences of the Republic of Armenia [14], only an advocate is indicated among the participants in the proceedings on administrative offences (Article 270). Among his rights are the rights to get acquainted with all the materials of the case; to initiate petitions; on behalf of the subject who invited him, to bring complaints on its behalf against the decision on the case.

The Code of the Republic of Kazakhstan on Administrative Offenses [15] in articles 748 and 755, respectively, establishes both the concept of "defender" and the concept of "representative of the victim". As a general rule, advocates participate as defenders under the legislation of the Republic of Kazakhstan. Along with advocates, the spouse, close relatives or legal representatives of the person brought to administrative responsibility are allowed as defenders. Foreign advocates are allowed to participate in the case as defenders, if this is provided for by an international agreement of the Republic of Kazakhstan with the relevant state on a mutual basis, in accordance with the procedure determined by law. In some cases, the participation of a defender in the proceedings on an administrative offense is mandatory (Article 749). The mandatory participation of a defender is established in cases where: the subject to administrative responsibility applies for this; the subject to administrative responsibility, due to physical or mental disabilities, cannot independently exercise his right to defense; the subject to administrative responsibility does not speak the language in which the proceedings are conducted; the subject to administrative responsibility is a minor.

Article 316 of the Code of the Kyrgyz Republic [16] on Offenses is called: "Defender, representative and lawyer". Despite this construction of the title, the participants in the proceedings on cases of administrative offenses are a defender and a representative, and an advocate is allowed as a defender or a representative.

The Code of the Republic of Moldova [17] on Offenses names a defender among the participants in the proceedings on administrative offenses (Article 392). According to the legislation of the Republic of Moldova, a defender is a person who has the right to practice advocacy and participate in proceedings on an offense in order to provide legal assistance or represent the party to whom he provides such assistance, on the basis of a contract or as a result of appointment as a coordinator of the territorial bureau of the National Council for StateGuaranteed Legal Assistance.

In accordance with Article 25.5 of the Administrative Code of the Russian Federation, the defender and the representative are allowed to participate in the proceedings on an administrative offense from the moment the case on an administrative offense is initiated. Currently, computer technologies and Internet resources have received serious development. The Covid-19 pandemic has shown the extreme demand for 
such technologies, but the Draft ProCoAO of the Russian Federation does not mention the possibility of providing legal assistance in proceedings on administrative offenses using Internet technologies.

Qualification requirements for a representative are not imposed either in the current Administrative Code of the Russian Federation or in the Draft ProCoAO RF.

\section{Conclusion}

Thus, one of the important directions of reforming the administrative-tort legislation is the creation of an effective mechanism to ensure the observance of the right of participants in proceedings in cases of administrative offenses to defense. To this end, it is necessary in the developed projects of the Code of Administrative Offenses of the Russian Federation and the ProCoAO of the Russian Federation to use a systematic approach to establish legal provisions aimed at regulating the mechanism for ensuring the observance of the right of participants in proceedings in cases of administrative offenses to defense.

\section{References}

1. Resolution of the Constitutional Court of the Russian Federation of 05/12/2021 No. 17-P "In the case of checking article 1.5, part 1 of article 2.1, part 1 of article 15.6, paragraph 1 of part 1 , part 3 of article 28.1 and notes to this article of Administrative Code of the Russian Federation in connection with the complaint of citizen N.N. Koretskaya"

2. Y. Anikeenko, N. Novoselova, About the concept of development of administrative and tort legislation, Digital Appendix to Russian Law Journal, 5 (2019)

3. Y. Anikeenko, N. Novoselova, Administrative and tort law: a textbook (Moscow, 2020)

4. Y. Popugaev, Prospects for improving the institution of legal assistance to a subject against which proceedings are being conducted on an administrative offense, Bulletin of Economic Security, 2 (2017)
5. Y. Serebryakov, Defender in proceedings on cases of administrative offenses: Ph.D. dissertation (Omsk, 2003)

6. Rossiyskaya gazeta on June, 1 (2020)

7. O. Chumakova, Free legal assistance in cases of administrative offenses, Journal of the Higher School of Economics, 1 (2016)

8. A. Ostapenko, E. Artemiev, E. Bevzyuk, Commentary on the Federal Law of November 21, 2011 No. 324-FZ "On Free Legal Aid in the Russian Federation"(itemized). Retrieved from: ConsultantPlus (2012)

9. E. Vitske, Realization of the right of citizens to receive qualified legal assistance in administrative jurisdiction - features of the participation of an advocate in a case of an administrative offense, Business in law, 1 (2015)

10. A. Shadzhe, S. Dzybova, A. Novichenko, Current issues of providing free legal assistance in the Russian Federation, Colloquium-Journal, 7 (2019)

11. A. Kosmynina, Ensuring the provision of qualified legal assistance to citizens, Bulletin of SUSU, 4 (2017)

12. Procedural and Executive Code of the Republic of Belarus on Administrative Offenses. Law of the Republic of Belarus No. 92-3 of 06.01.2021.

13. Law of the Republic of Azerbaijan No. 96-VQ of 29.12.2015

14. Code of Administrative Offences of the Republic of Armenia of 6.12.1985 (ed. of 10.10.2020) Official Gazette of the Republic of Armenia 23, 295 (1985)

15. Code of the Republic of Kazakhstan on Administrative Offenses. Law of the Republic of Kazakhstan of 05.07.2014 No. 235-V ZRK.

16. The Code of the Kyrgyz Republic on Offences. Law of the Kyrgyz Republic No. 58-VQ of 13.04.2017.

17. Code of the Republic of Moldova on Offenses. Law of the Republic of Moldova No. 218-XV of 24.10.2008

18. A. Baranov, Participation of the defender (representative) in the proceedings on cases of administrative offenses, Izvestiya YUFU (2009) 